\title{
Başka Bir Modernlik Hâli: Fikret Adil'in Eserlerinde İstanbul'un Bohem Hayatı
} Barış Berhem ACAR ${ }^{1}$

$\ddot{O} \mathbf{z}$

$\mathrm{Bu}$ çalışmada bohem hayatı, Fikret Adil'in kaleme aldığı Asmalımescit 74, Intermezzo ve Avare Gençlik başlıklı anlatılarından yola çıkılarak başka bir modernlik ihtimalini barındırması bakımından incelenmiştir. Fikret Adil'in 1930'lu yıllarda İstanbul'daki bohem hayatını anlattığı metinlerde değinilen bohemliğin sunduğu modernleşmenin, hâkim olan modernleşme hamleleriyle farklılıkları ortaya konmuştur. Hâkim modernleşmenin değerlerine karşı çıkan ve son tahlilde onun antiteziymiş gibi görünen bohemliğin de aslında ileri bir modernlik imkânını ifade ettiği, metinlerden yapılan alıntılarla ifade edilmiştir. Peyami Safa, Necip Fazıl gibi dönemin önemli edebiyatçılarıyla dost olan ve kitaplarında onlardan da bahseden Fikret Adil'in tanıklığıyla, sanat dünyasının resmî modernleşme hareketinin dışında, merkezden uzak bir hayat yaşamaları ve bunu bir savrulma olarak değil de asıl değer olarak görmelerinin koşulları tartışılmıştır. Böylece modernliğin tek tip olmadığı, farklı imkânların da değerlendirilmesi gerektiği saptanmıştır.
Anahtar Sözcükler

bohem hayat1

burjuvazi

modernleşme

Fikret Adil

Makale Hakkında

Geliş Tarihi: 10.02.2021

Kabul Tarihi: 08.06.2021

Doi:

10.20304/humanitas.877880

\section{Another State of Modernity: Bohemian Life of Istanbul in the Works by Fikret Adil}

\begin{abstract}
The present study examines bohemian life through narrations Asmalımescit 74, Intermezzo, and Avare Gençlik by Fikret Adil in terms of containing another modernity possibility. The texts by Fikret Adil, which define bohemian life in Istanbul in the 1930s, are chosen to demonstrate the differences between dominant modernization moves and the modernization offered by bohemians expressed in those texts. It is clear from the texts that bohemian which opposes the values of dominant modernization and seems to be its antithesis, expresses an advanced modernization possibility. A friend of significant authors of that time like Peyami Safa and Necip Fazıl, Fikret Adil bears a witness that the world of art lives ignoring official modernization moves and avoiding central orientations. This study argues why they perceived this as a main value rather than a drift. Therefore, the present study concludes that modernization is not a monotype but has different possibilities that should be seized.
\end{abstract}

\author{
Keywords \\ bohemian life \\ bourgeoisie \\ modernization \\ Fikret Adil
}

10.20304/humanitas. 877880

\footnotetext{
1 Arş Gör. Dr., Trakya Üniversitesi, Edebiyat Fakültesi, Türk Dili ve Edebiyatı Bölümü, Edirne/Türkiye. barisberhemacar@gmail.com, ORCID: 0000-0001-7294-7525
} 


\section{Giriş}

Modernite ortaya çıtı̆̆g andan itibaren bütün toplumsal dönüşümleri etkilemiş, ona değinmeden değişimleri ya da kırılmaları değerlendirmek imkânsız hale gelmiştir. Batı'da ortaya çıktıktan sonra Batı-dışı toplumları da zamanla etkisi altına alması, modernitenin kapsamını göstermesi kadar kaçınılmazlığını da ortaya koyar. Hatta modernite, kendisini geliştiren modernist paradigmalar kadar anti-modernist ya da modernite karşıtı hareketleri de kapsaması sebebiyle sınırları müphem, büyük bir ağ gibi görünür.

Modernite, doğası gereği, sadece kuramsal yaklaşımları değil, her seviyede karşıtlığ bir arada barındırabilme özelliğine sahiptir. Onun doğasında imkânlar ve kısıtlamalar bir arada görünür olur. Modernite, bir yandan kilisenin hâkimiyetinin kısıtlandığı, aklın ve teknolojik/bilimsel gelişmelerin ön plana çıktığı, yeni yaşam pratiklerinin günlük hayatın seviyesini yükselttiği imkânları barındırırken, diğer yandan ideolojik ve toplumsal savaşlarla ekonomik düzenin dönüşümünün yarattığı sıkıntılar, insanların bunalıma sürüklenmesine yol açmıştır. Modernitenin sorgulanmaya başlandığı dönemlerde, bu ikilikler tartışmaların ana eksenine oturmuştur.

Genel anlamıyla modernite, bir tarihi olay değil, tarihî olaylarla şekillenen bir süreçtir. Çünkü modernitenin ilgilendiği

modernlik ne bir hareket ne de bir akım olarak doğmuştur. Ne belirli bir programı ne de belirli düşünürleri mevcuttur. Coğrafî̀ keşifler ve rasyonel düşüncenin gelişmesiyle seküler dünya görüşünün yaygınlaşması Batı-Hıristiyan zihniyet ve yaşam biçimlerini köklü değişime uğratmıştır. Bu değişim yeni bir durum olarak algılanmış ve daha çok bilimsel bilgi, yeni teknik, ekonomik refah, istihdam artışı, işbölümü, boş vakit, siyasal katılım, özgürlük ve benzeri yeni ilgi alanları olarak zihinlere yerleşmesiyle yeni bir çağ olarak görülmüştür. (Metin, 2006, s. 14).

Berman ise moderniteyi üç evreye ayırır:

16. yüzyılın başlarından 18. yüzyılın başına dek uzanan ilk evrede insanlar, modern hayatı algılamaya yeni başlamışlardır; onlara neyin çarpmış olduğunu anlayamazlar henüz. Umutsuzca, el yordamıyla uygun sözcükleri bulmak için çırpınırlar; deneyim ve umutlarını paylaşabilecekleri modem bir kamu ya da camianın ne olabileceği konusunda pek fikirleri yoktur. İkinci evremiz 1790'ların büyük devrimci dalgasıyla başlar. Fransız Devrimi ve onun etkileriyle büyük, modem bir kamu, bir anda ve dramatik biçimde doğuverir. 20. yüzyllda, üçüncü ve son evremizde, modernleşme süreci neredeyse tüm dünyayı kaplayacak kadar yayılmış; gelişmekte olan modernist dünya kültürü sanatta ve düşünce alanında gözalıcı başarılar sağlamıştır. Öte yandan modem kamu, genişledikçe sayılamayacak kadar çok özel 
dillerde konuşan bir sürü parçaya ayrılır; sayısız, bölük pörçük şekillerde ele alman modernlik düşüncesi canlılığından, tınısından ve derinliğinden çok şey kaybeder; örgütlenme ve insanların hayatlarına bir anlam verme yetisini yitirir. (Berman, 1994, s. 29-30).

Sekülerleşme, rasyonalite, bireysellik ve kapitalizmin ortaya çıkmasıyla tesis edilen modernitenin en önemli sonuçlarından bir tanesi, burjuvaziyi ortaya çıkarmasıdır. Sekülerleşme, rasyonalite, bireyselleşme ve kapitalistleşmeyle var olmasını mümkün kıldığ1 burjuvazi, ortaya çıktığı andan itibaren bütün süreci yönlendiren sınıf olmuştur. Immanuel Wallerstein, burjuvazinin öncülüğünü "Modern dünyamız üzerine bildiğim hiçbir ciddi tarihsel yorum yoktur ki, burjuvazi [...] kavramını içermesin. Bunun bir sebebi var: Başkahramanı olmayan bir öykü anlatmak zordur.” diyerek vurgular (Akt. Moretti, 2015, s. 910). İlk olarak 17. yüzyılda tanımlanan ancak 18. yüzyılın sonlarına doğru, bugünkü anlamıyla sınıf hüviyeti kazanan burjuvazi, aristokrasiyle alt sınıfların ortasında iki sınıfın da bazı özelliklerini barındıran bir sınıf olarak tanımlanabilir. Burjuvazi bu dönemde "ağırbaşlı, rasyonel, zeki, dürüst ve kendinden çalışkanlıkla" eşdeğer görülmektedir. ${ }^{1}$ Hesaplılık, dikkat, akla yatkınlık, girişimcilik, daha fazlasını bulma arzusu, üretkenlik burjuvazinin çalışkanlıktan doğan ve onu besleyen özellikleridir. Burjuvazi, çalışarak "insanın gelişme, sürekli değişme, kişisel ve toplumsal hayatın her alanında sürekli altüst oluş ve yenilenme kapasite ve güdüsünü özgürleştirmek” için çabalarken duyguları bastırmaya, aklın egemenliğine firsat tanımaya gayret eder (Berman, 1994, s. 134). Ancak burjuvazinin çalışmayı saplantı haline getiren, sürekli üretmekle temellenen yükselişi, kendi içinde karşıtlarını da yaratır.

Burjuvazinin çalışkanlık, ahlak, bağlılık, ağırbaşl1lık, akılcılık gibi temel değerlerini yok sayan ve kendi doğrularıyla farklı bir moderniteyi deneyimleyen karşıtlarının başında bohemler gelir. Bohemler, "günübirlik yaşayan, belli bir adresi olmayan, özgür bir cinsel

\footnotetext{
${ }^{1}$ Burjuvazi üzerine en fazla düşünen isimlerden biri olan Karl Marx, "devrimci bir sınıf” olarak tanımladığ burjuvaziye, kötü özelliklerin yanında olumlu özellikler de yükler: Karl Marx, "Burjuvazi hâkimiyeti ele geçirdiği her yerde bütün feodal, ataerkil, kır yaşamına özgü ilişkilere son vermiştir. İnsanı tabii mafevkine bağlayan karmakarışık feodal bağları acımasızca kesip atmış ve insan ile insan arasında katıksız çıkardan, katı 'nakit ödeme'den başka bir bağ bırakmamıştır. Dinî bağnazlığın, şövalye ruhunun, küçük burjuva duygusallığının ilahî vecde gelişlerini bencil hesabın buzlu sularında boğmuştur. Kişisel onuru mübadele değerine dönüştürmüş ve sayısız müseccel ve müktesep hürriyetin yerine o tek, acımasız özgürlüğü, ticaret yapma özgürlüğünü, geçirmiştir. Sözün kısası dinî ve siyasi yanılsamaların ardına gizlenen sömürünün yerine açık, hayâsız, dolaysız, gaddar sömürüyü geçirmiştir. [...] Burjuvazi onca zamandır onurlu sayılan ve önünde huşuyla eğilinen her faaliyeti çevreleyen haleyi söküp atmıştır. [...] Burjuvazi aile ilişkisinin dokunaklı-duygusal örtüsünü yırtıp atmış, basit bir para ilişkisine indirgemiştir bu ilişkiyi. [...] Üretimin durmadan altüst edilmesi, bütün toplumsal koşulların aralıksız sarsılışı ve bitmek bilmeyen bir belirsizlik ve çalkantı burjuva dönemini öteki bütün dönemlerden ayırt eder. Bütün kemikleşmiş, donmuş ilişkiler arkaları sıra gelen eskiden beri saygıdeğer tasavvur ve görüşlerle birlikte silinip gider; yeni oluşanlar ise daha kemikleşmeye firsat bulamadan eskir. Katı olan her şey buharlaşıyor, kutsal olan her şey ayaklar altına alınıyor ve insanlar nihayet hayattaki konumlarına, karşılıklı ilişkilerine soğukkanlı bir gözle bakmaya zorlanıyorlar.” (Marx-Engels, 2014, s. 40-41).
} 
hayata açık, içki ve uyuşturucuya meyilli, düzenli çalışmayı sevmeyen, sıra dışı bir giyim tarzına sahip, uzun saçlı, radikal politik fikirlere hevesi olan ve geceleri yaşayan" kişilerdir (Siegel, 1999, s. 21). Süfli zevklerle, kaygısız ve arzulara göre yaşamanın düstur edildiği bohemlik, Fransa'da 19. yüzyılda yaygınlaşmıştır. Peyami Safa'ya göre bohem, "Mekân içinde sınır tanımıyarak enginleri kuşatmak için kabını çatlatmak istiyen ruhla vücut arasındaki savaşın destanı" anlamına gelir (Safa, 1990, s. 106-107). Sıradan olana benzemeyen bohemler, sıra dışı yaşam tarzlarıyla olağan olandan ayrılırlar. Bu ayrımın da farkındadırlar:

Kendinden gayrısını kalabalık sayan, sosyal hayata dair hiçbir kaygı taşımayan, sadece karanlık çökünce dışarıya çıkan ve gideceği eğlence merkezini cebindeki paranın miktarına göre belirleyen bu insanlar, toplumun genel ahlâk kurallarını da tanımadıkları için sosyal yapı içinde aykırılıkları ve nihilist tavırlarıyla belirmektedirler. Yabancı olduklarının farkındadırlar. Onları var eden şey de zaten bu uyumsuz hâlleridir (Yılmaz, 2014, s. 104).

Modern toplumu eleştiren sıradan olandan, materyalizmden ve kapitalizmden uzak durmayı seçen, saf ve özgün sanatın peşinde koşan genç sanatçılar olarak bohemler, bir vazgeçiş değil, burjuvazinin değerlerine karşı çıkıştır (Whiting, 1999, s. 67). Onları küçümseyen, yaşam tarzlarını değersizleştiren topluma başkaldırırlar. Lafargue'ye göre onlar, "[k]ural tanımaz, başına buyruk tavırlarıyla, asıl kendilerini aşağılayan toplumun bir hiç olduğunu gösterirler.” (Akt. Artun, 2013, s. 15). Ancak bu karşı çıkış, bir umudun ya da rahat yaşamın zevkleriyle değil, içten hissettikleri boğuntunun hatta azabın fragmanlarıyla doludur: Bohemlik bu gençler için,

[N]e bir vaat, ne de bir geçiş. Sanata adanmış ebedî bir hayat tarzı; hiçbir maddî beklentisi olmayan, sanatın adeta bir ibadete dönüştüğü bir çilekeşlik, bir inziva. Şana, şöhrete, fark edilme dürtüsüne ve bunların yayın piyasası tarafindan istismar edilmesine karşı bir direniş. $\mathrm{Bu}$ mezhepten bohemler, komünizm dâhil, zamanlarındaki bütün ütopyaların vaat ettiği ve nihayetinde sanata evrilecek bir hayata şimdiden ermiş gibi yaşarlar; ancak bu, vaat edildiği üzere bir kurtuluş değil, bir azaptır onlar için (Artun, 2013, s. 17). "’

Burjuvazinin günün saatlerini düzenleyerek "boş zaman” olarak ayırdığı süreci bütün hayatlarına yayan, günlerini sanatla veya keyif verici maddelerle geçiren bohemler, takdir edilenin dışında ama bir arada kolektif bir yaşam biçimini denerler. "Osmanlı İstanbul'unda 'harabati' olarak isimlendirilen bohemlik, burjuvazinin bireyselleşme, özgürleşme, farklılaşma, yaratıcılık, yenilikçilik, soruşturma, tartışma, hayal gücünü kullanma” gibi ölçütlerini ikiyüzlülüğe kapılmadan derinden yaşarlar (Acar, 2020, s. 127). Burjuvazinin değerleriyle kurulan "reel" dünyanın çeperinde, alternatif bir dünya yaratırlar. Makbul 
görülen modernite yeryüzünde yayılırken, bohemlik yeraltı dünyayı fetheder. Görünür olmayan, gizlendikçe çoğalan bir kolektif yaşam biçimini deneyimlerler.

Bohemliğin edebiyata yansıması da başkaldırıyla bağlantılıdır.

[B]ohem sanatçılar; kurallardan, plan ve programlardan uzak yaşarlar; hayallerini gerçek hayata uygulamaya, halüsinasyonlarını yaşamaya çalışırlar. Onlar için amaç, bilinmeyeni bulmak, görünmeyeni görmektir; şair ya da sanatçı, bilinmeyene ulaşmak için yenileri keşfetmek zorundadır (Dervişoğlu, 2010, s. 102-103).

Bohemler ilk keşfi kendi içlerinde yaşarlar. Toplumu yansıtmanın değil, kendi içlerindeki dünyayı yansıtmanın sanatçı olmanın amacı olduğunu fark ederler (Belge, 2017, s. 121-125). Özellikle sanatçılar arasında yayılan bohemlik, sanatsal üretim için gerekli görülmeye başlanır. Kentte toplumu yadsıyan sanatçılar, kendileri gibi olanlarla bohem bir hayat yaşayarak etkileşime geçer, kültürel alışverişte bulunarak sanatsal üretimlerini zenginleştirirler. Bohemi keşfetmek, sanatçıların üretimini zenginleştirmiştir. Bohem sanatçıların kendilerini keşfetmeleriyle birlikte burjuva modernleşmesinin temel öğretilerinin de dışına çıktıklarını, sıradan olandan ayrıldıklarını söylemek gerekir.

Tanzimat ile birlikte başlayan modernleşme hareketinde, burjuvazinin öne çıkardığ çalışkanlık, ilerleme, ahlak, bağlılık, ağırbaşlılık, akılcılık gibi değerlerini temel alan bir modernite algısı inşa edilir. Tanzimat münevverleri, Batı'nın tekniğini ve akılcılığını örnek alınacak, ahlakını ve yaşayış tarzını ibretlik hikâyeler olarak anlatırlar. Ahmet Mithat başta olmak üzere yeni Türk edebiyatı, çalışkanlığı teşvik eden, ailesine bağlı, sevgi dolu, maddi meseleler üzerine kafa yoran, bir Batılı gibi teknik gelişmeye hayran, ama bir Doğulu kadar ahlaklı ideal tipler üzerinden modernleşmenin sınırlarını çizerler. Kendi ahlaki değerlerini koruyup Batılı tekniği de edinince sorunların çözüleceğine inanırlar (Okay, 2008, s. 33-34). $\mathrm{Bu}$ anlayış, Osmanlı ve erken dönem Cumhuriyet modernleşmesinin itici gücü olur. Savaşlar ve kırılmalarla sürekli sekteye uğrayan modernleşme hamlesi kurumsallaşana kadar bu hâkim çizgide ilerler.

Batı'da burjuva modernleşmesine karşı tepki girişimleri olduğu gibi Türkiye'de de özellikle modernleşme hamlelerinin resmîleştiği süreçte bitmeyen savaşların yarattığ kırılmalar, tek sesliliğin hâkimiyeti ve ekonomik buhranlar, insanların bunalmalarına, kendi içlerine çekilmelerine sebep olmuştur. Büyük hedeflerin peşinde olmayan günübirlik yaşayan genç entelektüeller, dönemin atmosferinin ağırlığını bohem bir yaşayış tarzı benimseyerek atlatmaya çalışırlar. Gündüzleri yoğun çalışmak yerine geceleri eğlenceler düzenlemek, aile bağları yerine günübirlik ilişkiler yaşamak, toplumun ahlaki değerlerini benimsemek yerine 
Acar, B. B. (2021). Başka bir modernlik hâli: Fikret Adil'in eserlerinde İstanbul'un bohem hayatı. Humanitas, 9(18), 1-15.

onların altını oyacak bir yaşam düzenini deneyimlerler. Özellikle 1930'lu yıllardan sonra sanat ve edebiyat dünyasına sonradan büyük etki eden isimlerin gençliklerinde bu yaşam tarzını denemeleri, bohemliğin bu dönemde revaçta olduğunun göstergesidir. $\mathrm{Bu}$ dönemde bohem hayatının merkezinde olan kişilerin başında Fikret Adil gelir. Onun "Bohem Hayatı" alt başlığıyla yayımlanan otobiyografik romanları Asmalımescit 74, Intermezzo ile Avare Gençlik, bohem hayatın akışını anlamak için önemli kaynaklardır. Fikret Adil'in eserlerinin burada bohem hayatı anlamak için incelenmesinin temel sebepleri, onun hem bohem bir hayatı tercih etmesi, hem de bunu eserleri aracılığıyla kayıt altına almasıdır. Daha önce bu yönüyle incelenmeyen eserler, İstanbul'daki bohem hayatın dehlizlerine 1şık tutar.

Fikret Adil'in göz ardı edilen romanları, modernitenin kurumsallaştığı yıllarda alternatifi olan bohemliği de yarattığını, İstanbul'daki aydınlar arasında oldukça yaygın destekçi kitlesi bulduğunu gözler önüne serer. Ancak bu bohem hayat çok fazla anlatılmamıştır. Fikret Adil'i farklı kılan da budur. O eserleriyle bohem hayatı kayıt altına alarak, birçok aydının bohemliği terk ettikten sonra hatırlamak istemediği yılları detaylarıyla anlatmıştır. Bu yönüyle oldukça önemli olan eserler, çalışkanlık, vatanseverlik, ahlaklılık, bağlılık üzerine inşa edilen modernite algısının tam tersi bir modernite deneyiminin mümkün olabileceğini anlatır. Bu üç eseri, hâkim anlayıştan ayrılan yönleriyle incelemek, farklı bir modernlik algısının imkânlarını görmeyi sağlayacaktır. "Bu çalışmada, hem bohemliğin Fikret Adil tarafından nasıl anlaşıldığı, hem de onun anladığı manadaki bohemliğin hâkim anlayışa karşıtlığı metinlerden alınan örnekler üzerinden gösterilecektir.”

\section{Fikret Adil ve İstanbul'da Bohemlik}

Fikret Adil, İstanbul Çengelköy'de 7 Ocak 1901 tarihinde doğar. Tevfik Fikret'e hayran olan, bu yüzden oğluna Fikret adını veren babası askerî hekim, operatör Mahmut Adil Bey'dir. Fikret Adil, annesini küçük yaşta kaybetmiştir. İlk ve ortaöğrenimine Galatasaray Mekteb-i Sultanisinde devam eden Fikret Adil, Birinci Dünya Savaşı'nın çıkması ve babasının görev sebebiyle Yemen'e gitmesi üzerine okulu bırakarak çalışma hayatına atılır. Basın yayın işleriyle birlikte geçimini sağlamak için birçok farklı işte çalışır. Şirket-i Hayriye (1919-1920), Düyun-i Umumiye (1920-1922), Muhtelif Mübadele Komisyonu (1929-1930) ve Anadolu Ajansındaki (1930-1936) görevlerinden sonra uzun yıllar Türkiye İş Bankasında (1937) emekli olana dek görev alır (Kurdakul, 1973, s. 12). 1922'de Vakit gazetesinde tam zamanlı olarak başladığı gazeteciliği Tanin, Akşam ve Milliyet'te sürdürür. Daha sonra Cumhuriyet, Son Posta, Politika, İkdam, Son Telgraf, Ulus, Zafer, Haber, Tan, Yeni İstanbul ve Son Havadis gazetelerinde de çalışır. Gazetecilikle birlikte Artist isimli bir dergi de çıarır. 
Ayrıca Hareket, Yeni Adam, Ăgaç, S.E.S., Aydede, Yeditepe, Akis ve Meydan dergilerinde haber, fikra, hikâye, telif ve çeviri roman, röportaj, sanat kronikleri yazıları yayımlanır. Çevirmenlik ve yayınevlerine yayın danışmanlığı da yapan Fikret Adil, geçici görevler ya da gezi için Macaristan, Yunanistan, Kıbrıs, İtalya, Tunus, Cezayir, Fas, Libya, Mısır, Lübnan, Suriye, İngiltere, Hindistan, Hollanda, Pakistan’a gitmiş, sinemayla da ilgilenmiş, sinema eleştirileri kaleme almıştır. Evi uzun yıllar, sanatçıların toplandığı mekân işlevi görmüştür. Sanatla dolu bir hayat yaşayan Fikret Adil, yakalandığı Parkinson hastalığının tedavisi için gittiği İsviçre'de 1973 yılında vefat eder (Mehmetoğlu, 2021). Bir yandan sanatın her dalıyla ilgilenmesi ve eleştirel yazılar yazması, diğer yandan Beyoğlu başta olmak üzere bohem hayatı yansıttığı eserleri ve bohem çevrelerle dostluğu, onu döneminin önde gelen sanat kişilerinden biri yapmıştır (Uysal, 2021). Özellikle eserleri, 1930’lu yıllarda hayatını bambaşka şekilde anlayan ve yaşayan bohemliğin kodlarını anlamakta oldukça değerlidir.

\section{Fikret Adil'in Eserlerinde Bohemlik}

Fikret Adil'in bohem hayatı anlattığı üç eserinden Asmalımescit 74'te kitaba adını veren binada yaşamaya başlayan bir gazetecinin aşklarına, ailesi ve arkadaşlarıyla ilişkilerine, sorumluluk almamasına, eğlenceden ibaret bir hayat yaşamasına odaklanılır. Roman, modernitenin çarklarından sıyrılmış, hayatını modern toplumun kendisinden beklediğinin dışında yaşayan başkarakterin İstanbul'daki bohem tecrübelerini gözler önüne serer. Otobiyografik denebilecek eserde, anlatıcı ses, hayatı anlatılan gazeteciye aittir. Necip Fazıl'dan Peyami Safa'ya kadar birçok aydın, isimleriyle birlikte bohem çevrelerdeki yaşayışlarıyla eserde kendine yer bulur.

Intermezzo isimli romanda, Rum tiyatrocu Pappas ile İstanbullu zengin Musevi bir ailenin kızı Tina'nın sansasyonel aşkına odaklanılır. Bununla birlikte, o dönemdeki sanat çevrelerinin ilgilerine, yaşayış biçimlerine, birbirleriyle ilişkilerine ve hayata bakışlarına şahitlik edilir. Aile bağları gibi modern toplumun en fazla önem verdiği ilişkiler ağından birinin adeta altı oyulur.

Avâre Gençlik te ise aynı kadından hoşlanan üç gencin, birbirlerinden haberdar olarak kadın karakterle yaşadıkları aşk ve birbirleriyle ilişkileri konu edilir. Ahlaki normların hükmünün kalmadığı bir ortamda, içlerinden geldiği gibi yaşamayı seçen gençler, hiçbir değer yargısıyla cezalandırılmadan bütün gerçeklikleriyle anlatılırlar. Her üç anlatı da aslında Osmanlı'dan beri var olagelen modernleşme hamlesinin bilinçli olarak dişında kalan, başka bir hayatın imkânlarını arayan ve bunu bohemlikte bulan kişilerin ilişkilerini, ahlaklılığa bakışını ve hayatı tanımlamalarını, çalışmaya ve sorumluluk duygusuna atfedilen değeri 
Acar, B. B. (2021). Başka bir modernlik hâli: Fikret Adil'in eserlerinde İstanbul'un bohem hayatı. Humanitas, 9(18), 1-15.

sorgulamalarını gözler önüne serer. Anlatıların sonunda "yasaya uymayan" karakterlerin cezalandırılmadığı, hatta anlatının hep onların yanında durduğu sezdirilerek bohemliğin de bir seçenek olduğu vurgulanmıştır. Bu eserlere bohemliğe verdikleri değer üzerinden bakmak farklı bir modernliğin de mümkün olabileceğini düşündürür. En azından, Fikret Adil, İstanbul'da bohem bir çevrede yaşadıktan sonra bu dönemin utanılacak ya da ibret olarak görülebilecek bir dönem şeklinde algılamayıp her şeyiyle sahip çıkabilmenin potansiyelinin olduğunu gösterir.

\section{Hâkim Olanın Aksine Bağsızlığın Yüceltilmesi}

Fikret Adil'in eserlerinde ön plana çıkan en temel izleklerden birisi kişisel ilişkilerdir. Aile, sevgili ve arkadaşlık bağlarının köhneleşmesi ve ilişkilerinin kaypaklığı, bu eserlerde doğal bir süreç olarak anlatılır. Sadakat, aileye karşı sorumluluk ya da evlenmenin kutsiyeti yerine gönlünün istediğiyle birlikte olan, ailesine bağlı olmayan veya aile kurmayı aklından bile geçirmeyen karakterler, yaşam tarzlarıyla burjuva modernleşmesinde hâkim olan değerlere açıktan karşı çıkmış olurlar. Asmalımescit 74 ün gazeteci ben-anlatıcısı, anlatı boyunca ailesinin yanına sadece bir defa uğrar. Yirmi yedi gün boyunca sevgilisi Jorjet'le kendisini eğlenceye kaptırıp sağlığı bozulana kadar dağıldıktan sonra ailesinin evine gider, toparlanana kadar orada kalır. Kendisine geldiği gibi yeniden Asmalımescit'teki 74 numaralı binaya döner. Bu yirmi yedi gün her şeyden vazgeçerek, sırf süfli zevkler için yaşamanın örneğini sergiler: “Tam yirmi yedi gün, uykusuz, sarhoş, yorgunluğumu ve hislerimi tahrik için Jorjet'in bizzat aldığı ve bana aldırdığı muhtelif 'drogue'ların verdiği sun'î hayatiyetle yaşadım. Tam yirmi yedi gün, pek az fâniye nasip olan bir ihtiras devresi geçirdim, işi gücü unuttum" (Adil, 2018, s. 59).

Kendinden geçecek kadar etkilendiği bu günlerin ardından eve giderek dinlenir, Salı gününden Cumartesi gününe kadar uyuyarak kendine gelebilir. Sonrasında yeniden eski hayatına döner. Ailesine dair hiçbir detaya girmez, ancak ailesi de ona karşı suçlayıcı davranmaz. Bu bağsızlığı, iki taraf da olağan karşılar. Kadınlarla ilişkileri de sadakat içermez, anlatı boyunca birçok kadınla birlikte olur. Hepsinden başka bir şey aldığını söyler: "Düşünüyordum. Jorjet beni vücudu ve kafasıyla tatmin etmişti. Piri etimi doyurmuştu. Edit ise sadece zekâsıyla çekiyordu" (Adil, 2018, s. 88). Burada sayılanlar dışında da ilgi duyduğu kadınlar vardır. Bağlılığı hiç düşünmez. Hatta ona göre bağlılığın sembolü olan evlilik, günübirlik ilişkilere tercih edilebilecek bir şey değildir. Kendisinde "koca" olacak istidadı görmez: 
[B]en, kendimde, kanunun 'koca 'diye tarif ettiği insan kabiliyetlerini görmüyorum. Eğer ben evlenecek olsam muhakkak surette ya karım, ya ben, birimizden biri betbaht olur. Bu tehlikeye girmektense aşk denilen geçici evlenmelerin kısa fakat daima ve sade işin tatlı acılarını kendisinde toplayan vaziyetlerini tercih ederim (Adil, 2018, s. 88-89).

Oysa burjuva modernliği, bu tarz ilişkileri hep yüceltirken, en önemli değer olarak ahlakı ön plana koyar.

Aile ve evlilik bağlılıklarına mesafeli duran, birine bağlanmayı önemsemeyen benanlatıcı, çocuğu olduğunu öğrendiğindeki tepkisizliğiyle burjuvanın değerlerinin altını oymaya devam eder. Yirmi yedi gün birlikte süfli zevkleri sonuna kadar tattığı Jorjet'ten ayrıldıktan sonra bir mektup alan ve çocukları olduğunu öğrenen ben-anlatıcı, babalık hissinin de "kocalık" gibi kendisine uzak olduğunu söyler: "Bu haber beni hiç de sarsmıyor. Evet, baba muhabbeti, kan çekmesi gibi bir şeyler düşünmüyorum. Sadece tatlı bir maceranın gururu okşıyan memnuniyeti” (Adil, 2018, s. 134). Aile, sevgililik ve babalık bağlarını önemsemeyen ve bunu normal olarak anlatan, toplumsal değerlere sahip çıkmadığı için “cezalandırılmayan” ben-anlatıcı, alışılmışın dışında bir yaşam tarzını yansıtmış olur.

Bağsızlık meselesi, Fikret Adil'in diğer iki eserinde de görülür. Intermezzo'da Rum oyuncu Pappas ile zengin Musevi kızı Tina'nın aşkına tanıklık ederken, aile, din ve aşkı kapsayan bağlılıkların ne kadar zayıf olduğu fark edilir. İkili, farklı inanca mensup olmalarına rağmen, dinî bağlılıkları olmadığı için, bu durumu aşklarını yaşamalarına bir engel olarak görmezler (Adil, 2015, s. 42). Dinle olduğu gibi aileyle bağları da zayıftır. Tina, âşık olduğu Pappas'la evlenmek için ona hep iyi davranan ve kültürlü yetişmesini sağlayan ailesini geride bırakarak onunla birlikte Yunanistan'a kaçar. Ancak babası kızını, geri döndürmek amacıyla peşinden gider. Babasıyla özellikle para meselelerini konuştuktan sonra nasıl olduğunu bilmediğimiz bir şekilde ikna olan Tina, Pappas'ın yanına dönmez. Tina'nın kendisinden vazgeçtiğini gören Pappas ise arkadaşlarının teşvikiyle onu kaçırmaya karar verir. Babasıyla yalnız yakaladıklarında Tina’yı kaçırmayı planlarlar. Uzun bir takip süresinden sonra böyle bir fırsat ellerine geçer. Planlarına göre Pappas, tanınmamak için farklı bir arabada oturacak, Tina ile babası sokakta yalnız kalınca diğer arabadaki fedailere mendil sallayarak harekete geçmelerini sağlayacaktır. Ancak Pappas, Tina ile babasının sokaktan güle eğlene konuşarak geçtiklerini görünce harekete geçmez. Pappas'ın harekete geçmemesine şaşıran arkadaşlarına cevabı bu büyük aşkın yüzeyselliğini gösterir:

-Ne yaptın be? Niçin mendili sallamadın?

Pappas, gayet sakin cevap verdi: 
-Mendilim yoktu da ondan.

Ve kahkahayı bastı (Adil, 2015, s. 100).

İnanç, aile bağları gibi anlatı boyunca ön plana çıkarılan büyük aşka bağlılık da Araba Sevdası romanının sonunda Bihruz'un büyük aşkının ardından başka bir arabanın peşine takılması gibi bir anda böylece bitmiştir. En derin gösterilen bağlılık bile, mücadele edilmesi gerektiği anda yok olur ve bu oldukça olağan karşılanır.

Avâre Gençlik'te de bağsızlık normal bir mesele gibi görülür. Modernleşmeyle birlikte kabul gören ahlaki kıstaslara zıt olarak, arkadaş olan iki erkeğin aynı kadından hoşlanması, kadının ikisini çeşitli durumlarda yarıştırıp yine arkadaşları olan bir üçüncü erkeği hakem tayin ederek birini seçmesi, sonrasında ise hakem tayin edilen erkekle birlikte olmaya başlaması anlatılır. Aşkın bağlılığının yok sayıldığı, cinsellik başta olmak üzere toplumda tabulaşan meselelerin yarış aşamalarına dönüştürüldüğü anlatıda, ahlaki sınırsızlık, sürekli deneyimlenir. Zaten romandaki karakterlere göre "Bir cemiyette ahlak ölçüleri, kıstasları değişirse, bundan müteessir olacaklar onlara bağlı kalanlardı”[r] (Adil, 2014, s. 38). Onlar için ahlak, geri zihniyetlerin ördüğü, arzuları yok sayan bir duvardır (Adil, 2014, s. 90-92). Bağlılıkları olmayan, birbirlerinden haberdar olarak "sakıncalı" ilişkiler yaşayan ve bunu aynı diğer romanlardaki gibi olağan gösteren Fikret Adil, bohemliğin, kurumsallaşan, takdir edilen ve modernleşmeyi üstlenen sınıfların önemli gördüğü bağlılıklara değer vermediğini ortaya koymuştur.

\section{Yüceltilen Çalışma Aşkının Karşısında Tembellik Hakkı}

Bohemlerin anlatılarda, ana akıştan farklı gördükleri bir diğer izlek, çalışma hayatına dairdir. Boş zamanın sınırlandırılmasından, çalışmanın teşvik edilmesine kadar, değer verilen her anlayışın tamamen zıddı bir tavırları vardır.

Paul Lafargue, eskiden kölelere özgü olduğunu söylediği çalışma için ‘tüm düşünsel yozlaşmanın, tüm bedensel bozukluklarının sebebi” der (Lafargue, 2010, s. 12). İktidarların çalışmayı sürekli övmesini de eleştiren Lafargue, tembellik hakkının gerekliliğini de vurgular. “Aylaklığın zevklerinin tadı tuzu"nu özellikle işçilerin tatması gerektiğinden bahseder (Lafargue, 2010, s. 39). Çalışma aşkı yerine çalışmama hakkını kullanan bohemler de, “aylaklığın zevklerinin tadı tuzu”nu tatmayı şiar edinmiş gibidirler. Boş zamanın belirlenmesi başta olmak üzere, moderniteyle mümkün olan yeni ekonomik düzendeki çalışma disiplininin tümüyle dışında yaşarlar. Hatta hayatları çalışan insanların günlük rutininin tersine akar. Asmalımescit 74'te ben-anlatıcı herkesin işe gittiği saatte kendilerinin gece eğlencesinden eve 
döndüklerini söyler: "Saat dokuz olmuştu. Herkes işine giderken, biz yatmaya dönüyorduk." (Adil, 2018, s. 55).

Aslında Fikret Adil'in kendisi gibi gazeteci olan ama bazen günlerce gazeteye uğramayan, gittiğinde de yarım gün kalabilen ben-anlatıcısı, sıklıkla aylak geçen bir gecenin sabahı işe gitmenin zorluğundan yakınır: "Sabahlanan gecelerin ertesi günü çalışmak bana hayatta öyle bıkkınlık veriyordu ki, o dakikada işi gücü bırakarak uyumak istiyordum.” O, çalışmayı tembellik yapabilmek için bir vasıta olarak gördüğünü söyler: "Benim gibi çalışmayı, daha iyi tembellik edebilmek için bir vasıta telâkki edenler bu hissimi çok iyi anlarlar" (Adil, 2018, s. 28).

Genelde mesaili işlerde çalışmayan, oyunculuk, yazarlık gibi daha yaratıcı ve kısıtlayıcılığ́ olmayan işlerle uğraşan kahramanlar, modern çalışma düzenini ayakta tutan zamanın saatlerle bölümlere ayrılan düzenlenmesine de karşı çıkarlar. Íntermezzo'da "Muayyen saatte iş, muayyen saatte uyku, muayyen saatte yemek, muayyen saatte bilmem ne... İnsanın dünya üzerinde saate esaretinin neticeleridir. Göreceksiniz, bütün dünyada, herkes saatlerini alıp kırsın, derhal yepyeni bir âlem yaratmış oluruz.” denir (Adil, 2015, s. 62). Ancak vurgulamak gerekir ki, bohemlerin, aylaklıktan anladıkları, hâkim olan modernleşme anlayışı tanımından farklıdır. Onların düzene uyum sağlamamayı tercih etmeleri, bunu değersiz görmelerinden ileri gelir. Yoksa kendilerine yapılan eleştirilerdeki gibi miskince aylaklık yapmak gibi bir amaçları yoktur. Asmalımescit 74 te ben-anlatıcı bu durumu açıkça vurgular:

Memleketimizde bohem hayatı yaşayan sanatkâr pek azdır. Kahve peykelerinde uyuklıyan, koltuk meyhanelerinde endaht'a giden, sinema kapılarında kavga çıkaran sahte muharrirler kendi zanlarına göre bohemdirler. Bu, sadece bayağılıktır. Üzerlerinde çalışmadıkları gayri münteşir eserlerinden bahseden bir güruh, dejenere ve çanak yalayıcıdan başka bir şey değildir.

Hakikî bohem, her şeyden evvel çalışır ve sanat eseri meydana getirir. Eğer bu eserde devrinin ilerisine geçerse, anlaşılmazsa bu onun kabahati değildir. Ve bohem kazanır ve bütün kazancını bir günde bitirir (Adil, 2018, s. 96-97).

"Hükümlerden, mesuliyetlerden olduğu gibi kaçınmayı, hür, başıboş yaşamak için şart say"an kahramanların, Avâre Gençlik'te de merkezde olduklarını söylemek gerekir (Adil, 2014, s. 105). Her üç anlatıda da çalışma hayatları geri planda olan ya da hiç olmayan, çalışmayı aylaklık için bir araç olarak görmeleri, onların uzun vadeli bir hayat planlamasından ziyade an'1 yaşamayı düstur edinmelerinden kaynaklanır. Asmalımescit 74 te ben-anlatıcının sevgililerinden biri olan Lili’nin "Benim için mazi, mevzuat, günün telâkkileri yoktur” der 
(Adil, 2018, s. 25). Ben-anlatıcı ise "Yalnız yaşanılan dakikanın 'sahi'si ve 'yalan'ı vardır" şeklinde düşünür (Adil, 2018, s. 135). Bunlarla birlikte anlatılardaki şairlerin şiirlerini o gecelik eğlence için yok pahasına satmasının anlatılması gibi detaylar verilir. Bu örneklerden de anlaşılacağı üzere bohemler için önemli olan, o an yaşanandır. Onlar, modern toplum anlayışlarının geleceği düşünmeyi salık veren fikirlerinin tam tersi bir düzene tabidirler.

\section{Bohemlerin Gece Hayatına Bakışı}

Düzenin şartlarına karşı çıkan bohemler için gece hayatı oldukça önemlidir. Osmanlı'dan itibaren Batı'dan alınmasından en çok korkulan yaşam tarzının başında gelen ve hep Beyoğlu’yla özdeşleşen gece hayatının zararlı görülmesi anlayışının tersi olarak bohemler için çalışmak, gündüzün resmiliğine dayanabilmek gecenin cazibesiyle mümkündür. Fikret Adil'in anlatılarında da bir bağımlılık gibi görülen gece hayatı ön plandadır. Her üç anlatıda da olayların anlatıldığı şehirlerin gece hayatı en fazla anlatılan detaylarıdır. Anlatılarda, Beyoğlu, Paris ve Atina'daki gece hayatı, o şehirleri tanıtmak için en önemli ayrıntılar olarak sunulur. Üzüldüklerinde de, en mutlu anlarında da soluğu gecenin deriliklerinde alan kahramanlar için bu yaşayış tarzı vazgeçemedikleri, hatta vazgeçmek istemedikleri hayattan zevk alma yöntemidir. Asmalımescit 74 ün ben-anlatıcısına göre gece hayatının tadı bir kez alındı mı bir daha vazgeçmek imkânsızdır: "İnsan zevk ve gece hayatının bir defa tadını tattı mı, artık ondan güç kurtulabiliyor. Fakat ben, kurtulmak için hiçbir gayret sarfetmiyordum. Çünkü bu hayat esasen hoşuma gidiyordu, ondan kurtulmaklığım için bir sebep yoktu." (Adil, 2018, s. 67). Bohemlerin gece hayatını kurtulmak gereken bir hastalık olarak değil de hayatın gerçek tadı olarak görmesini, Fikret Adil'in metinlerinde detaylı olarak anlatması hâkim modernleşme hareketinden ne kadar ayrı durduklarını belli eder.

\section{Sonuç}

Moderniteyi Fransa üzerinden tanıyan ve modernleşme serüvenini Batı'nın tekniğini alıp, ahlakını göz ardı etmenin üzerine kuran Osmanlı modernleşmecileri için bir aşırılık olarak görülebilecek bohemlik, Cumhuriyet'le birlikte İstanbul'da bir grup sanatkâr arasında yayılmış, ancak Batı'daki gibi yaygınlık kazanmamıştır. Örneklerini görsek de bohemliğin ana akıma dönüşmediğini söylemek gerekir. Bohemlik, genç sanatçılar arasında bir dönem yaşanılan bir hayat tarzı olarak kalmış gibidir. Bu sınırlılık sebebiyle bohemlikten bahseden eserler, görece azdır. Sayıca az da olmasalar, bu eserlerde anlatılanlar oldukça önemlidir. Fikret Adil'in kaleme aldığı ve bohem yıllarını anlattığı otobiyografik romanlar da bu sebeple dikkate değerdir. Üzerinde fazla durulmayan bu metinlerde, hâkim modernleşme ideolojisinin 
değerlerini yok sayan kahramanlar vasıtasıyla bohemliğin sunduğu modernlik halini görmek mümkündür.

Fikret Adil'in romanlarındaki karakterlerin yaşayış biçiminden yola çıkarak, hem bohemliğin onun tarafından nasıl algılandığı, hem de modernitenin farklı bir şekilde de yaşanabilmesinin imkânları ortaya konur. Onun eserlerinde aile, arkadaş, sevgili ya da eşe bağlılı̆̆1 değerli görmeyen; böylece hâkim modernleşme hareketinin üzerine bina edildiği ahlaki değerleri göz ardı eden bohem karakterler, bu değerleri yok sayarak da yaşanabileceğini gösterir. Yaşam tarzlarıyla, kişisel ilişkilerin bambaşka şekilde kurulabileceğini vurgularlar. Benzer şekilde, özellikle burjuvazinin modernite süreçlerine hâkim olmasıyla değeri iyice artan çalışma hevesinin bu eserlerdeki bohemler tarafından değersizleştirildiği görülür. Çalışmak, anlık zevkleri yerine getirecek güce sahip olmak için önemlidir. Onun dışında bir hayat tarzına dönüşmez. Geleceği düşünmek, daha rahat bir hayat yaşamak yerine çalışılan gece bütün kazanılan paranın harcandığı, para lazım olunca çalışıldığ1 bir yaşam şeklini benimserler. Ayrıca modernleşirken hep kötülüklerle bağdaştırılan gece hayatını her şeyin üzerinde bir değer olarak görmeleri de bohemlerin bilinçli olarak bambaşka bir modernliği deneyimlediğini açıkça ortaya koymaktadır. Sağlıklarına dikkat etmeyen, hiçbir şeye bağlanmayı önemsemeyen, gece yaşamayı, gündüzleri görünür olmamayı tercih eden bohemler, diğerleri tarafından süreli eleştirilseler ve yok sayılsalar da genel geçer olanın tamamen dışında kalan değerleriyle yaşamayı sürdürürler.

Bu çalışmayla, Fikret Adil'in eserlerinin farklı gözle tekrar okunmasının, bohem meselesini anlamada önemli olduğu gösterilmeye çalışılmıştır. Böylece bohemlik gibi Türk edebiyatında aydınlar arasında yaygınlaşan ama pek bahsedilmeyen bir anlayışın örneklerine değinilmiştir. 


\section{Kaynakça}

Acar, B. B. (2020). Türk romanında antikahramanlar. (Yayınlanmamış doktora tezi). Trakya Üniversitesi, Edirne.

Adil, F. (2014). Avâre gençlik. İstanbul: Ayrıntı Yayınları.

Adil, F. (2015). Intermezzo. İstanbul: Ayrıntı Yayınları.

Adil, F. (2018). Asmalımescit 74 (2. baskı). İstanbul: Ayrıntı Yayınları.

Artun, A. (2013). Baudelaire'de sanatın özerkleşmesi ve modernizm. Modern hayatın ressamı içinde (s. 7-86). İstanbul: İletişim Yayınları.

Belge, M. (2017). Artistik Bohemya'nın yükseliş ve çöküşü. Tarihten güncelliğe içinde (s. 121-125). İstanbul: İletişim Yayınları.

Berman, M. (1994). Katı olan her şey buharlaşıyor. (Ü. Altuğ-B. Peker, Çev.) İstanbul: İletişim Yayınları. (Orijinal çalışma basım tarihi 1982).

Çiğdem, A. (1997). Bir imkan olarak modernite. İstanbul: İletişim Yayınları.

Dervişoğlu, E. (2010). ‘Bohem’ kavramı ve ‘Bir Tereddüdün Romanı’ üzerine. Folklor/Edebiyat Dergisi (62), 101-116.

Marx, K. ve Engels F. (2014). Komünist manifesto (2. bask1). (N. Satlıan, Çev.) İstanbul: Yordam Yayınları. (Orijinal çalışma basım tarihi 1974).

Kurdakul, Ş. (1973). Şairler ve yazarlar sözlüğ̈̈. Ankara: Bilgi Yayınevi.

Lafargue, P. (2010). Tembellik hakkı. (F. Şahin, Çev.) İstanbul: Parşömen Yayıncılık. (Orijinal çalışma basım tarihi 1883).

Mehmetoğlu, F. (2021, 26 Nisan). Fikret Adil. Türk edebiyatı isimler sözlüğü. http://teis.yesevi.edu.tr/madde-detay/fikret-adil

Metin, C. (2006). Türk modernleşmesi ve İran (1890-1936). (Yayınlanmamış doktora tezi). Hacettepe Üniversitesi, Ankara.

Moretti, F. (2015). Tarih ile edebiyat arasında burjuva. (E. Buğlalılar, Çev.) İstanbul: İletişim Yayınları. (Orijinal çalışma basım tarihi 2013).

Okay, O. (2008). Batı medeniyeti karşısında Ahmed Midhat Efendi (4. bask1) İstanbul: Dergâh Yayınlar1.

Safa, P. (1990). Objektif: 6 yazarlar, sanatçılar, meşhurlar (3. bask1). İstanbul: Ötüken Yayınlar1.

Siegel, J. (1999). Bohemian Paris: culture, politics, and the boundaries of bourgeois life, 1830-1930. Baltimore, Maryland: The Johns Hopkins University Press.

Uysal, Ö. (2021, 28 Ocak). İstanbul'da bir bohem: Fikret Adil. Post Dergi. http://postdergi.com/istanbulda-bir-bohem-fikret-adil/ 
Acar, B. B. (2021). Başka bir modernlik hâli: Fikret Adil'in eserlerinde İstanbul'un bohem hayatı. Humanitas, 9(18), 1-15.

Whiting, S. M. (1999). Satie the bohemian: From cabaret to concert hall. New York: Oxford University Press.

Yılmaz, M. (2014). Şairlerin bohem hayatı üzerine gözlemler. Selçuk Üniversitesi Türkiyat Araştırmaları Dergisi, (36), 101-114. 